\title{
John Locke and His Educational Thought - Between Tradition and Modernity of Enlightenment ${ }^{1}$
}

\begin{abstract}
The text presents pedagogical thought of the Seventeenth century philosophy of John Locke, representative of English empiricism and forerunner of Enlightenment. The author considers how much Locke's modern philosophical views powered his educational concept and on the other hand to what extent this pedagogical field retained in his description the conservative character and why/for what reason. This combination of tradition and modernity in Locke's philosophy are shown by the example of his reffering on one hand to reason and on the other to the truth; then to freedom and equality in the light of law and at the same time to the natural law; to experience and social diversity, and finally to skepticism about the original sin and the goodness of man's nature. The author also points out the strengths and the weaknesses of the mixture of traditional and modern views of Locke as a pedagogue and connects some of them more with a purely liberal profile of this philosophy than with the Enlightenmental philosophy.
\end{abstract}

Key words: education, exploring childhood, Enlightenment, freedom, reason, virtue, experience, truth, natural law, good habits, pedagogical optimism

Słowa kluczowe: edukacja, odkrywanie dzieciństwa, Oświecenie, wolność, rozum, cnota, doświadczenie, prawda, prawo natury, dobre nawyki, optymizm pedagogiczny

1 The first version of this text was published in "Pedagogika Filozoficzna on-line", 011-12, No. 1, p. 77-99 under the title Johna Locke’a koncepcja wychowania-zapowiedź Oświeceniowych przemian w myśli pedagogicznej. 


\section{Introduction}

John Locke is a $17^{\text {th }}$-century English philosopher and educator, writing in a specific historical context as reflected by the issues addressed in his main texts. They may be seen as a response to the questions faced by the society of that era. At the same time, the way they were approached went beyond the ideas of his times and announced the use of new tools and methods of describing reality; it announced the Enlightenment.

In the opinion of his native, British historians and theoreticians of education, John Locke is an unquestionable leader, expert on the subject and a promoter of progress. Robert Rusk ranks him among the Great Educators alongside Plato, Quintilian, Loyola, Comenius, Rousseau, Pestalozzi, Herbart, Froebel, Montessori and Dewey, at the same time referring to Whitehead's famous words about the impossibility to revert to the old position after the shock of a great philosopher (Rusk, Scotland, 1979, p. 1). For many, Locke also served such a function; it was possible, however, thanks to the publicity and an indepth reception and analysis which followed his works in France, Germany, the Netherlands or the United States. It is doubtful whether it happened in Poland on a similar scale. ${ }^{2}$ What distinguishes them all, according to Rusk, is the fact that even though they created their works in a specific place corresponding to the challenges of a given time, their instructions seem to transcend their specific historical context and become universal so that we continue to refer to their works, searching for suggestions or ideas that could be used nowadays. The group of great thinkers in the history of education may be diverse; however, in Rusk's view it can be linked thanks to five common factors. First, each of them inscribed or highlighted his theory in the description of the educational process; second, to a greater or lesser degree, all of them were philosophers; third, they were innovators, and therefore their ideas were not in harmony with their own epochs, taking on a critical or even revolutionary turn; fourth, they were to manifest themselves, and effectively at that, in the practice of education; and fifth, this manifestation was to be relatively lasting and not ephemeral (Rusk, Scotland, 1979, p. 2-5). We can consider Locke's input in the theory and practice of education from this point of view, at the same time bearing in mind the primary objective of this paper, which is to name the features of his writing that would indicate the announcement of the Enlightenment changes in the area of education.

2 From the point of view of the development of Polish pedagogical thinking, the reception of Locke's philosophy in our country is a topic that is worth considering separately, see on this topic e.g. (Wrońska, 2015, p. 15-35). This paper takes into consideration mainly the resonance and evaluation of Locke's pedagogical concept in the area of the English culture and language. 


\section{Historical and Cultural Context of Locke's Writings}

Discussing Locke's contribution to civilizational transformations in his country and in Europe, with a particular focus placed on its educational dimension, we should not lose the context in which his theoretical reflections were placed. According to S.J. Curtis (Curtis, 1967, p. 113-115) Locke came to be viewed as one of three critics, alongside Francis Bacon and John Milton, of the $17^{\text {th }}$ century school and academic education in England. Each of them emphasised its fascination with the culture of Antiquity, verbalism, fossilised and archaic teaching methods based mainly on the art of memory, and education limited to discipline forced with a rod. Neither a modern - in the $20^{\text {th }}$ century categories - definition of education proposed by Milton, aimed at educating a person who would be well equipped to act in a just, competent and generous way both in private and public area, in times of peace and war (Ainsworth, 2007, p. 55; Quick, 1890, p. 214), nor Bacon's postulates for educational system not to be limited to the scholastic school of thinking centred on words but open to knowledge about things provided through new, experimental ways of learning, found their reflection within the framework of the existing model of education. Biting comments made by Locke with reference to grammarschools (also known as public schools) and medieval universities in Oxford and Cambridge remained similarly unnoticed. The three scholars, with their educational background solidly based on the existing educational model, ${ }^{3}$ to a certain extent legitimising that system by the very fact of belonging to and representing corporations of scholars or educators, were at the same time ardent critics of that environment. However, this also explains why their attempt to distance themselves from the existing model of education could take a form of literary criticism, but not an open engagement in the transformation of the entire system; a form of a postulated educational reform with reference to social groups presented by them, but not in the meaning of a universal reform that would ensure some form of education, if not necessarily in the same form, for all children at a given age, regardless of their social background. ${ }^{4}$ According to Robert H. Quick, in the case of Milton there was little behind his announcements of reforms in terms of the educational content because the author, focused on antique books and education based on Latin texts, did not manage to

3 F. Bacon - a graduate of Trinity College in Cambridge, J. Milton - a graduate of St. Paul's School in London and Christ's College in Cambridge, and J. Locke - a graduate of Westminster School in London and Christ Church College in Oxford.

4 In this respect, bolder projects were proposed by other writers of the time, e.g. a Scottish puritan John Dury and a scholar Sir William Petty, not to mention the views and activities of Samuel Hartlib, a close friend of Comenius and the promoter of his ideas in England. 
free himself from the influence of verbalism, thus remaining without sufficient understanding of the state of mind of young students which would allow to propose specific examples of improvements in terms of the teaching process (Quick, 1890, p. 215-218). Curtis voices a similar opinion on Locke, claiming that in his shift from the level of criticism to the level of specific proposals he remains equally impractical as Milton, unable to give up his encyclopaedism (Curtis, 1967, p. 114-115). On the other hand, writing about the need to include in the education of a young person a wide range of subjects (from mathematics and geography, through physics and astronomy, to history and legal and moral issues) providing a basis of general knowledge, Locke defends himself quite effectively from having his concepts narrowed down to the limited framework of utilitarianism. ${ }^{5}$ The author of Some Thoughts Concerning Education sees the solution to the problem of an antiquated form of public education in promoting training at home under the supervision of a private tutor. Among the English aristocracy (as opposed to mainland Europe), such an opinion was prevalent in practice, and its additional confirmation and reinforcement by an authoritative opinion of a scholar meant that accepted models of education became even more preserved, thus postponing the required restructuring and reform of schools. It was within the home environment that this all-encompassing process of development, maturing and preparing the child for a responsible adult life was to take place under the watchful eye of parents or a tutor. Locke, a pioneer of liberalism, was far from entrusting this task to the state and government. For him, proper education was the primary care and duty of the family, and at the same time it came to be regarded as acting for the glory of the nation and the country.

Despite voicing what seems to be a rather cautious and conservative opinion concerning the place of children's education, ${ }^{6}$ it is quite a widespread belief, especially in the Anglo-Saxon circles, that Locke's ideas viewed in their entirety paved the way for and announced a new trend, i.e. the Enlightenment, with all its manifestations and transformations which ensued in the $18^{\text {th }}$ century in the mental, social, political and educational culture, and subsequently also in the practical life in England, later in the United Kingdom

5 Although still facing a harsh criticism e.g. from J.H. Newman for using a utility criterion with reference to education (Newman, 1996, p. 108-126).

6 On the basis of the Scottish philosophy of education, a discussion with Locke's idea was undertaken by G. Turnbull, who in many respects followed the ideas contained in Some Thoughts Concerning Education, in this regard, however, advocating the middle way ("the right way lay in the middle between private and public education", p. 33), thinking of small groups of 7-8 students under the supervision of a teacher, in which it is possible to appeal to a healthy and motivating impulse to compete, see id. Turnbull, 2003, p. 32-40. 
of Great Britain and, on a broader scale, in Europe and the United States. ${ }^{7}$ In order to capture the distinguishing features of this thought, it is impossible to look at Locke's philosophy selectively, searching for them in some selected, privileged areas. Pedagogical thought seems to be an important, though until recently often overlooked in philosophical reflections, element of it. ${ }^{8}$ According to P. Schouls, Some Thoughts Concerning Education together with Of the Conduct of the Understanding ${ }^{9}$ constitute a pair of complementary texts dedicated to the education of a child and self-education of an adult in his lifelong process of maturing and choosing a path of conscious freedom, this issue being an important element of Locke's philosophy alongside such areas as epistemology and political philosophy, which are best explored and represented by such works as An Essay Concerning Human Understanding and Two Treatises of Government. It is stressed that Locke's contribution to pedagogy results mainly from the fact that the author discussed an issue of education and based it fully on his modern understanding of philosophy, thus turning the issue into a subject of a thoughtful and in-depth analysis, pretending to the status of a general, universal reflection, written as it were by a renowned philosopher. Its significance is not diminished by the fact that the main work was dedicated to his friend, E. Clark, and the advice contained there was to help educate a specific child. On the contrary, this proved to work to its advantage as the work was written not in the language of an abstract treatise, but in the form of a guide which expressed the essence of the approach it promoted. Instead of another impersonal textbook formulating a set of rules applicable in the process of directing and disciplining children and training them in the course of learning, it introduced a new, individualised approach to a child, his development and education. It was no longer the child who had to adapt to the programme, but instead the programme was to be adapted to the child (Axtell, 1968, p. 52). On the other hand, it can be assumed that a work dedicated to education would not have lost anything but rather would have benefited from Locke's more careful examination of the current pedagogical literature, as pointed out by R.S. Quick in his critical introduction to Some Thoughts Concerning Education (1880). Then a lot of the issues addressed by the pedagogues of that time might

7 See e.g. Himmelfarb, 2005, p. 3-22, which argues that the British Enlightenment particularly affected and pervaded (as described in the categories of the sociology of virtue) the American culture and its form of the Enlightenment, referred to as the politics of liberty.

8 The change of approach is evidenced in the works of e.g. P. Gay, J. and J. Yolton, N. Tarcov, W.M. Spellman, P. Schouls or L. Ward.

9 Locke's entire thought concerning education also contains other works: Some Thoughts Concerning Reading and Study for a Gentleman of 1703, Of Study of 1677 as well as letters with pedagogical advice written to a number of people (including e.g. the Duchess of Peterborough or Lady Masham). 
have become part of his own reflections (Quick, 1880, p. xlviii-xlix; Axtell, 1968 , p. $62-65)^{10}$. J.W. Yolton, in turn, defends him, asserting that the unique quality of Locke's approach to education is due to this hands-on and thus direct (as opposed to indirect - based on treatises) knowledge of children, an insight into their world gained through his own pedagogical experience, that is, a thoughtful observation and experience in working with pupils and students in the course of his life. As a result, the reading of Some Thoughts Concerning Education evokes in the reader a conviction as to the importance of the subject matter addressed by the author, supported by commitment and expertise in presenting specific practical solutions and instructions, e.g. concerning the child's general interest in learning or cultivating a certain habit or unlearning some bad inclinations (Yolton, Yolton, 2003, p. 12-14).

Summing up the matter of historical-cultural context of Locke's works, it is agreed that, as regards his pedagogical writings, they give testimony mainly to the influence of the Christian tradition, humanism, courtesy tradition and rationalism (Mason, 1965, p. 70-71), which is evidenced with the presence of more often implicit than express references to such authors as Pierre Nicole, François Fénelon, Claude Fleury, Michel Montaigne, Baldassare Castiglione and René Descartes. Furthermore, it would be difficult to overlook an obvious, following from his general education, influence of classical philosophers, starting from Aristotle, Quintilian, Juvenal or Desiderius Erasmus. At the same time, the way he transcended this context, as discussed in more detail below, allows to follow Peter Gay in his referring to this philosopher and pedagogue as the father of the Enlightenment in pedagogical thought and beyond it. In his view, An Essay Concerning Human Understanding is a text that provided psychological bases for a modern theory of education, and creating together with Some Thoughts Concerning Education as an application of the philosophy a coherent whole with the first work, soon became and has since remained a classic in the area of philosophy (Gay, 1964, p. 1).

10 It is a fact that in Locke's library there was a lack of important for the pedagogical thought of the $16^{\text {th }}-17^{\text {th }}$ century works of native writers such as Roger Ascham, Sir Tomas Elyot, Henry Peacham, Richard Mulcaster, John Brinsley or Charles Hoole; it is assumed that Locke was not familiar with John Milton's “Of Education” or numerous pedagogical works by Comenius; however, he had some French texts concerning this topic, including M. Montaigne and P. Nicole, as well as Italian Il libro del Cortegiano by B. Castiglione. 


\section{Locke Heralds the Enlightenment}

The Enlightenment can be described as an integrated movement of ideas forming a relatively uniform trend characterised by a specific set of contents that is new with regard to the previous epoch. However, at the same time it can be treated in terms of a specific, i.e. overlapping with the $18^{\text {th }}$ century and placed in various parts of Europe time referred to as the Age of Enlightenment. The latter interpretation gives way to a broader and more diverse understanding of the epoch, taking into consideration various philosophical concepts, which are sometimes difficult to reconcile yet are ultimately complementary. ${ }^{11}$ For Peter Gay, who dedicated at least three important works to the Enlightenment, it is an epoch which lends itself to the description through the prism of four significant factors, which means that it is expected to have certain qualities, for some reason ascribed to it; on the other hand, it is also characterised by various manifestations of a discussion with the dominant rite, inclusive of its negation. Firstly, philosophes are described as having "an unmeasured faith in a rigid mechanical reason" (Gay, 1964, p. 269), however, it would be more justified to say that they were critics of rationalism and metaphysics based on it (vide Descartes) and viewed reason in terms of an important yet limited power in the hands of man (Diderot, Hume, Kant). Secondly, they are characterised in terms of the advocates of the idea of progress, yet at the same time the optimism ascribed to them should be juxtaposed with their attitude of criticism (Diderot), scepticism (Hume) or cynicism (Gibbon) or, in fact, even pessimism (Holbach). The second characteristic is associated with the third one; namely no sense of history in the meaning of an understanding for the past and tradition. The proof of transcending this determinant of the epoch lies in notable historical texts authored by philosophes (Voltaire, Gibbon and Hume). Although the Age of Enlightenment unquestionably abandoned an uncritical approach to the past that allowed the prejudice, stereotypes and superstitions to continue, still its founders, as noted by Gay, were "also convinced that the only way to escape from the past was to know it" (Gay, 1964, p. 274). Fourthly, the Enlightenment suggests a devotion to the idea of an enlightened monarch, who accompanied by philosophes will be able to pursue the mission of implementing the project of a perfect society. This view, associated mainly with Voltaire, Diderot and d'Alembert as a token of respect for Empress Catherine the Great or Frederick the Great, can be balanced with an increasingly

11 Following P. Gay, let us mention six philosophers associated with the Enlightenment and creating its "family", though remaining very different from each other: Samuel Johnson and Voltaire, Charles Wesley and Gotthold Ephraim Lessing or Alexander Pope and David Hume (Gay, 1969, p. x). 
more frequent in the Enlightenment debate about the chances of promoting the idea of citizenship and ways of civilising largely illiterate societies (Gay, 1964, p. 274-277). If we add to this characteristic a division suggested by Gertrude Himmelfarb (Himmelfarb, 2005, footnote 11), with her differentiation between the sociology of virtue, the ideology of reason and the politics of liberty as three distinguished forms of the Enlightenment: English, French and American, we could venture a conclusion about a considerable diversity within the scope of philosophical reflection upon the shape of the $18^{\text {th }}$ century and include within it such values as: reason, progress, liberty, rights, nature, truth, morality, improvement, education. Although if we assume that the Enlightenment was to a greater degree a movement of ideas rather than a social change (Gay, 1964, p. 288-290), which is the most noticeable in the area of education, then those values best be considered in a specific mutual relationship and proportions set by the proposal of a given thinker. Therefore, in what arrangement are they found in Locke's philosophy? Looking at it through the prism of his educational thought mainly, how suitable is he for the role of the precursor or father of the Enlightenment?

\section{Locke between a Revolutionary and a Conservative Ideas}

An apt introduction to the philosophy of education formulated by Locke can be found in Gay's words contained in his work John Locke on Education. His interpretation inclines towards the image of Locke as both a conservative and revolutionary thinker, "at once transmitting and transforming traditional ideas" (Gay, ed., 1964, p. 1). ${ }^{12}$

The revolutionary character of his opinions manifests itself primarily in viewing reason as an unerring guide in the process of cognition and determining the rules of thinking and acting, as a natural faculty which elevates man over other creatures as long as he wants to use it (and not be controlled by passion or lower sensual motives), as a touchstone allowing to distinguish appearances (such as circular opinions, superstitions and stereotypes) from the truth. Conservatism, in turn, is associated with a general anti-systemic attitude which points to the inability to cognize everything about the nature of the uni-

12 R. Grant and N. Tarcov speak in a similar vein when stating in the Introduction to Locke's political doctrine derived from such principles as natural equality, rights of individuals, power based on social understanding, right to civil resistance to injustice of the ruling parties, the separation of state and church, rule of law, as the reasons which in the contemporary US political debate often become the property of liberalism as well as conservatism (Grant, Tarcov, ed., 1996, p. vii). 
verse, emphasising the vastness of human ignorance and weakness of human nature, and at the same time recognising the truth as the aim of knowing and reasoning for. ${ }^{13}$

Another factor suggesting both a revolutionary and conservative character of Locke's thought is the view concerning the freed om of every individual as a being that is not subject to the power of any other person and his equality in the light of law. However, this argument is not determined by any arbitrary will but by virtue of the natural law established by God. This law sets the framework and direction of human freedom. Therefore, this is not the right to freedom but freedom in accordance with the dictates of reason, and these determine both rights and obligations in relation to oneself and others. ${ }^{14}$

Another revolutionary proposal is to abandon the Cartesian assumption of the existence of innate ideas and defend the thesis of genetic empiricism stating that human mind is initially a blank slate (tabula rasa), which is then gradually written on thanks to the acquired experience and reflections based on it. If so, the conservative character of his thought will in turn manifest itself in consideration concerning the actual social and cultural condition of people, which at the starting point sets very diverse paths for people coming from different social groups and strata, although it does not eliminate the possibility of social advancement. Locke is far from justifying human poverty

13 This combination of reason and truth distinguishing Locke's axiology is pointed out by Quick, reinforcing the opinion through the reference to the statement by Lady Damaris Cudworth Masham in a letter to Leclerc, in which she calls her friend a servant of truth always following reason ("He was always, in the greatest and in the smallest affairs of human life, as well as in speculative opinions, disposed to follow reason, whosoever it were that suggested it; he being ever a faithful servant, I had almost said a slave of truth; never abandoning her for anything else, and following her for her own sake purely") (Quick, 1890, p. 220).

14 This is well expressed in the following quotations from Locke's texts: "Where there is no law there is no freedom" (Locke, 2009, p. $2 \$ 57$ ), "Understanding without liberty would be useless, and liberty without understanding (if there could be such a thing) would signify nothing” (Locke, 1825, p. II, $21 \S 67$ ), “Thus we are born free as we are born rational” (Locke, 2009, p. $2 \$ 61$ ), "If to break loose from the conduct of reason, and to want that restraint of examination and judgment, which keeps us from choosing or doing the worse, be liberty, true liberty, madmen and fools are the only freemen" (Locke, 1825, p. II, $21 \$ 50$ ). "But a liberty to dispose and order freely as he lists his person, actions, possessions, and his whole property within the allowance of those laws under which he is, and therein not to be subject to the arbitrary will of another, but freely follow his own" (Locke, 2009, p. $2 \$ 57$ ), "that one should do as he would be done 'unto"'(Locke, 1825, p. I, $3 \$ 4$ ). The presence of the motif of the law of nature in Locke's thought as the pioneer of liberalism is pointed out by John Dunn, who emphasises its importance for the legitimisation of the system of liberal democracy, voicing fears, however, as to the condition and binder of such a state having rejected the reference to God's order and remained only at the level of individual axiom of self-actualisation, with its possible tendency to egoistic reductionism (Dunn, 2008, p. 38-43). 
and misery with the fact of social inequality; his texts do not provide support for the advocates of the theory of class conflict; after all, "Men's happiness or misery, as he will say in Some Thoughts Concerning Education, is most part of their own making" (Locke, 2003, \$1). There is more pedagogical optimism (Schouls, 1992, p. 185; Gay, 1969, p. 512) in those words than metaphysical pessimism: what matters in life is fortitude, hard work, and effort put in overcoming barriers and life obstacles together with kindness and help in relation to other people. ${ }^{15}$

The fourth revolutionary component of Locke's thought is the abandonment of the doctrine of the original $\sin ^{\prime 16}$ although at the same time it should be pointed out that it contains a conservative motif negating as strongly the goodness of human nature (which would be contrary to the tabula rasa thesis); Locke drew this conclusion when observing children, in whom he saw a tendency, often manifesting itself very early, to dominate and get their own way, as well as a general weakness of reason, that is a dependence on feelings and passions and a tendency to indulge sensual pleasures, with people finding it difficult to free themselves from such weaknesses throughout their entire life. A remedy to this state of affair is to equip children with good habits, that is, to cultivate their moral character (i.e. virtues). Here the set of education areas proposed by Locke can be best explained and justified, with virtue taking the leading position as the goal of education and the learning and acquisition of knowledge being placed at the very end of the spectrum. ${ }^{17}$

15 Locke's social philosophy had an influence on Benjamin Franklin, the most characteristic spokesman for bourgeois morality and the idea of self-made man. This theme is particularly emphasised by P. Schouls, who does not find in Locke's works any basis that would allow to explain one's situation in terms of being the product of a given environment; quite the contrary, there is no situation that would release one from taking responsibility for oneself as no conditions remove a duty of self-improvement (Schouls, 1992, p. 185-187).

16 It is in this argument more than in the rejection of innate ideas that P. Gay sees the unique quality of Locke's approach, which encouraged the reinforcement of the belief in the power of education which could not be held to such a degree even by the most optimistic Christians, believing in the need for God's grace in consequence of original sin (Gay, 1969, p. 511).

17 Locke introduces this topic in Some Thoughts Concerning Education with the sentence: "That which every Gentleman (that takes any care of his Education) desires for his Son, besides the Estate he leaves him, is contained (I suppose) in these four Things, Virtue, Wisdom, Breeding, and Learning” (Locke, 2003, \$134) and in the following paragraphs justifies this hierarchy of the four areas of education. Degradation of learning will gain Locke a lot of criticism. The most ardent criticism in terms of its tone and influence came from Cardinal Newman, who accused Locke not only of a narrow utility-driven approach to knowledge but also of an attitude of disregard for the efforts of teachers and work put in the improvement of learners' minds. See discussion with the criticism (Quick, 1880, p. lv-lvii). According to Quick, and it is difficult not to agree with this interpretation, on the one hand, Locke's best defence against the allegation of pedagogical utilitarianism is his elevation of moral education over instructing; on the other hand, 
It can be seen that conservatism in the four mentioned ideas follows mainly from that fact of taking into consideration and distinguishing in the analysis of human nature one stage of life, namely childhood. Having the following extractable defining features in the form of categories of: reason, freedom, truth, virtues, it is possible to add with full conviction to the set of philosophical defining features of Locke's thought the concept of education. Paradoxically, from the point of view of humanities and social and historical sciences, this conservatism provided the foundations for, and gave rise to, Locke's equally revolutionary achievement as the four abovementioned theses; seriousness and accuracy with which Locke, based on his long-term work with children and careful observation of their world, took upon himself to describe the phenomenon of education is a powerful chord with which he marked his input in the long process of discovering childhood (Gay, ed., 1964, p. 1-4). He achieved it without abolishing the role fulfilled at this stage of life by others, i.e. adults responsible for children. Education itself as a space in which childhood takes place, a stage of life on the way to becoming an independent adult, a self-responsible person, assumes in Locke's works a rank of human affairs, hence the necessity to coordinate the abovementioned concepts: reason, freedom, truth, virtues with the possibilities and needs of childhood in which education occurs. It seems that in this area, a considerable part of Locke's intuition marked its presence as strongly on the stage announcing the Enlightenment, and perhaps it even became part of the canon of knowledge about man; nevertheless, there are also some weaknesses of his pedagogical thought which are worth bearing in mind.

\section{Defining Features of J. Locke's Pedagogical Thought - Its Strengths and Weaknesses against the Norms of the $17^{\text {th }}$ Century}

Taking into account the fact that, as pointed out by Gay, the $17^{\text {th }}$-century views on education inclined towards egalitarian democracy would demonstrate their author's extreme utopianism, "having his head in the clouds" (Gay, ed., 1964, p. 15) ${ }^{18}$ Locke's pedagogical thought, although in accordance with the norms

it seems surprising that a philosopher concerned with the analysis of human mind does not appreciate the importance of exercising mind (analogical to exercising character) and focuses only on how useful specific knowledge is (Quick, 1880, p. l-lv).

18 "Egalitarian democracy in education would have seemed the wildest of Utopian dreams to men in Locke's time" (Gay, ed., 1964, p. 15). 
of the times formally addressed to a specific social group, mainly the English aristocracy, and proposing only parish "working schools" for the poor, was nonetheless considered to be radical. The main points of the thought are widely known and there is no need to present them again, therefore I will mention only three voices illustrating the ways of describing Locke's contribution to the matter of education. The first one recommends his texts to all those who are interested in the pedagogical theory providing an answer to the question of why we really want to educate children; to follow Peter Gay, the author of the opinion, it is worth reading for those who

seek a philosophy that insists on the relevance of subject matter to experience without neglecting the pleasure of cultivation for its own sake, that emphasizes recognition of the child's needs without ignoring the uses of discipline, that urges the relation of morale to learning without denying the virtue of hard study, that seeks to form men and women fit to modern life without forgetting that this fitness requires cultivation of the higher sensibilities and a profound knowledge of the great literature of the past (Gay, ed., 1964, p. 15).

This evaluation clearly indicates the span or polarity of Locke's thought, analogically to some degree to the previously described mosaic of ideas which constitutes the whole known as the Enlightenment.

James Axtell, in turn, focuses on articulating defining features of a general educational method contained in Locke's work. In his opinion, its main components include: firstly, work on forming right habits throughout childhood; secondly, the importance of a dual principle: concern for the esteem and reputation and fear of the loss of one's good name (sensitivity to shame and disgrace) as means of discipline; thirdly, a good example provided by adults in place of blank and easily forgotten rules or admonitions; fourthly, questioning corporal punishment as not fulfilling its purpose; fifthly, giving children freedom and place for moments of fun, thus allowing them to be themselves as children; furthermore, paying attention to personality traits and temperament as well as the pace of development distinguishing children and adapting the programme of education to them (rather than the other way round: adapting children to the programme) (Axtell, ed., 1968, p. 52-53). Personally, I would add one more suggestion made by Locke to the list, i.e. the requirement to treat children with dignity and respect, manifesting themselves in e.g. not pointing out their mistakes in public or carefully listening to their statements, questions or requests and not leaving them without reply.

The third approach to the proper education that can be derived from Locke's works is proposed by P. Schouls. According to him, they present 4 suggestions (Schouls, 1992, p. 207-225): Firstly - (1) obedience in the name of subjecting desires and preferences to control (a prominent role of reasonable tutors), then - (2) yielding desires to the judgment of reason, in accordance with the defini- 
tion of virtue, which consists in "denying ourselves the satisfaction of our own Desires, where Reason does not authorize them” (Locke, 2003, \$38), then (3) instilling a principle (together with exercising a habit) that the satisfaction of a desire should be dictated by whether it leads to true happiness ${ }^{19}{ }^{19}$ not, it should be denied. Due to the fact that a child is usually unable to make an informed decision about it, parents should decide whether to postpone or deny it, and submission to their will can be easily linked with the need developed in children to take care of their good name and deserve respect and acceptance. All this serves to achieve one aim - (4) that is, autonomy. Indulging children would not allow them to develop freedom but only submission to their own preferences. As Locke states, "He that is not used to submit his Will to the Reason of others when he is young, will scarce hearken to submit to his own Reason when he is of an Age to make use of it” (Locke, 2003, \$36). Schouls' interpretation suggests that Locke's (external) coercion inscribed in the nature of educational process may be interpreted as an exercise in acquiring an ability to be led by one's reason, that is, to obtain autonomy as the aim of education, in accordance with one of the definitions of liberty as a power "to act or not to act, according as the mind directs" (Locke, 1825, p. II, $\$ 71$ ). Coercion and liberty remain contradictory as no one can be forced to be a free man, to be he's own master, yet education is this very type of experimental field which provides room for children to exercise their own freedom and reason, although not on a voluntary basis but rather to the degree corresponding to their ability to control their inclinations, without parents waiving their position of responsible guardians taking care of and guiding children towards adulthood and self-responsibility. ${ }^{20}$

These several examples of finding in Locke's thought the main themes revealing an enlightened and innovative approach towards the education of children, the implementation of which often took a long time in social life practice, finally brings us to the question about the motifs which are equally highlighted in this thought and act as a sign of weakness, inconsistencies and errors and perhaps even going back in the development of pedagogical thought and practice. Locke himself spoke of his calling as a philosopher in

19 In the text Thus I Think Locke distinguishes 5 types of goods with which we can ultimately associate lasting pleasure and happiness: (1) health, (2) good name, (3) knowledge, (4) good deeds, (5) hope for eternal happiness (Goldie, 1997, p. 296; Reicyn, 1941, p. 211-212).

20 This process does not need to succeed in finding one's life path based on reasonable freedom therefore for Schouls it remains a problematic issue whether the category of progress and pedagogical optimism following from it could ultimately characterise Locke's pedagogical idea (Schouls, 1992, p. 225-232). 
terms of being an 'under-labourer' rather than 'master-builder. ${ }^{21} \mathrm{He}$ carried out this modest (though at the same time working like a 'broom') task that for many people proved to be revolutionary ${ }^{22}$ in its fight against verbalism, its search for unquestionable principles and directives for practising sciences, philosophy and theology, in the way it abolished numerous superstitions disguised as truths and prepared the ground for the Kantian principle of sapere aude; nevertheless, in some places it proved too reducing.

A rational approach to virtue as an ability to control oneself, i.e. an ability to deny oneself the satisfaction of desires where reason does not allow it and a hedonistic concept of will, ${ }^{23}$ together with scepticism about an attitude which equips man with an internal sense guiding one towards goodness and beauty, ${ }^{24}$ did not allow Locke to see the aesthetic values of nature and human creativity that can be accessed through feelings. ${ }^{25}$ Hence the lack of references to artistic and aesthetic education, which is unquestionably a huge limitation

21 As he wrote in The Epistle to the Reader as the introduction to An Essay Concerning Human Understanding: "The commonwealth of learning, is not at this time without master-builders, whose mighty designs, in advancing the sciences, will leave lasting monuments to the admiration of posterity, but everyone must not hope to be a Boyle, or a Sydenham; and in an age that produces such masters, as the great Huygenius and the incomparable Mr. Newton (...), 'this ambition enough to be employed as an under-labourer in clearing ground a little, and removing some of the rubbish, that lies in the way to knowledge" (Locke, 1825, p. x-xi).

22 Unlike Descartes, whose rationalism displeased philosophes, Locke aroused their enthusiasm and hope (probably by softening the range of uncertainty in knowledge, which resulted from the adoption of the assumptions of genetic empiricism), although the radicalism of the method of doubting the certainties of exiting knowledge was similar in both Descartes and Locke.

${ }^{23}$ Locke verifies his original opinion on what determines the will, and in the second edition of Essays Concerning Human Understanding he states that it is not "the greater good in view" but a state of dissatisfaction, "an uneasiness of the mind for the lack of some absent good" (Locke, 1825 , p. II, \$31), adding elsewhere that "The motive for continuing in the same state or action is one's present satisfaction in it, the motive to change is always some uneasiness. The only thing that ever leads us to will a change of state or the performing of a new action is some uneasiness with our present state or action. This is the great motive that works on the mind, getting it to act. (...) I shall call this determining the will” (Locke, 1825, p. II, \$29).

24 In place of a natural inclination towards the good, in the course of moral argumentation Locke introduces a reference to the category of external system of sanctioning (following C. Taylor), which is present in people's moral choices due to divine reward and punishment (Taylor, 2001, p. 470-475).

25 This missing theme will be skilfully developed by Locke's student, A.A.C. Shaftesbury (in such works as An Inquiry Concerning Virtue and Merit, The Moralist, A Philosophical Rhapsody or A Letter Concerning Enthusiasm). The motifs of punishment and reward fulfil for him a conditional role, as the moral merit is ultimately determined by good intentions and an effort dedicated to good deeds, and these can be developed and improved in contact with the beauty of nature and culture, thanks to tolerant education, forming a generous disposition, based on the qualities of human nature such as the inclination towards the goodness and the possession of good feelings. 
of his entire pedagogical proposal. Another excessively radical trim employed by Locke seems to be his failure to see the value of an effort dedicated to intellectual work; it is all the more surprising for the fact that with reference to the cultivation of moral character he appreciates an analogical effort and labour associated with the denial of various goods. Would it not have been reasonable to apply a similar principle in relation to the forming of intellect? Does not the fact of overcoming weaknesses and resistance to the act of thinking and reasoning have a genuine value following from the improvement of the power of the mind and the strengthening of will at the same time? This underestimation of both topics directly concerning the area of education may be explained with Locke's attitude of placing virtue before learning (these referring to it only indirectly), yet it does not sound too convincing.

These questions and doubts give rise to others. For example, did Locke, in his dedication to promote the idea of reason, succumbed himself to the enthusiasm which he fought against? Is the refusal to listen to one's feelings a manifestation of it? Is it not caused by the fear of the power of feelings and passions, which in turn activates a more or less open determination to combat them? Does it not, in a way, manifest the extreme nature of his views? Furthermore, does he not, in his attempt to expose stereotypes and prejudices of his epoch, present dependence on them when, under the influence of negative experiences connected with his own education, he criticises public education without trying to raise above his grudges and propose a reform? At the time of the approaching Enlightenment, washing one's hands of the problem of education and referring the matter to private families was not in line with the general tendency of the age and delayed necessary educational reforms of schools and universities as a public issue (Curtis, 1967, p. 114-118; Barnard, 1961, p. xvi-xvii).

It turns out that the attempt to announce a new movement, i.e. the Enlightenment, made on the example of the works of the author of Some Thoughts Concerning Education reveals some doubtful chords alongside strong and affirming ones. This suggests the need to refer to further inspirations derived from other sources and using other means to proceed into the $18^{\text {th }}$ century. This also invites to further reading of Locke's writing and to formulate the final conclusion that with reference to certain traditional and modern issues Locke manifested himself as the father not so much of the Enlightenment as of the emerging philosophy of liberalism. 


\section{Bibliography}

Ainsworth O.M. (ed.) (2007). Milton on Education. The Tractate of Education with Supplementary Extracts from other Writings of Milton. Cornell Studies in English, New Haven.

Aldrich R. (2006). Lessons from history of education. Routledge, London-New York.

Axtell J. (ed.) (1968). The Educational Writings of John Locke. Cambridge University Press, Cambridge.

Barnard H.C. (1961). A History of English Education from 1760. University of London Press, London.

Curtis S.J. (1967). History of Education in Great Britain. University Tutorial Press, London. Dunn J. (2008). Western Political Theory in the Face of the Future. Cambridge University Press, Cambridge.

Gay P. (1969). The Enlightenment: An Interpretation, 2: The Science of Freedom. Alfred A. Knopf, New York.

Gay P. (ed.) (1964). John Locke on Education. Teachers College Columbia University, New York.

Gay P. (1964). The Party of Humanity. Essays in the French Enlightenment. Alfred A. Knopf, New York.

Goldie M. (ed.) (1997). Locke. Political Essays. Cambridge University Press, Cambridge. Grant R., Tarcov N. (ed.) (1996). Introduction, in: J. Locke, Some Thoughts Concerning Education and Of the Conduct of the Understanding. Hackett Publishing Company, Inc., Indianapolis, p. vii-xx.

Himmelfarb G. (2005). The Roads to Modernity. The British, French, and American Enlightenments. Vintage Books, New York.

Kant I. (2000). Co to jest Oświecenie?, transl. A. Landman, in: Z. Kuderowicz, Kant. Wiedza Powszechna, Warszawa.

Locke J. (2003). Some Thoughts Concerning Education. J.W. Yolton, J.S. Yolton (eds.). Clarendon Press, Oxford.

Locke J. (1825). An Essay Concerning Human Understanding. Thomas Tegg, London. Locke J. (2009). Two Treatises of Government. Cambridge University Press, Cambridge. Mason M.G. (1965). The Literary Sources of John Locke's Educational Thoughts. "Paedagogica Historica”, Vol. 5, no. 1, p. 244-290.

Newman J.H. (1996). The Idea of a University. F.M. Turner (ed.). Yale University Press, New Haven \& London.

Ossowska M. (1966). Myśl moralna Oświecenia angielskiego. PWN, Warszawa.

Quick R.H. (1880). Some Thoughts Concerning Education by John Locke. Cambridge University Press, Cambridge.

Quick R.H. (1890). Essays on Educational Reformers. D. Appleton \& Co., London. 
Reicyn N. (1941). La Pedagogie de John Locke. Hermann \& C. Éditeurs, Paris.

Rusk R.R., Scotland J. (1979). Doctrines of the Great Educators. The MacMillan Press, New York.

Schouls P.A. (1992). John Locke and Enlightenment. Cornell University Press, Ithaca and London.

Sztobryn S. (1998). Z tradycji kształcenia pedagogicznego w XVII wieku - refleksje wokół Johna Locke’a, in: T. Jałmużna, R. Więckowski (eds.), Pedagogika wczesnoszkolna $i$ kształcenie nauczycieli w Polsce i Słowenii. Uniwersytet Łódzki, Łódź, p. 223-234.

Taylor Ch. (2001). Źródła podmiotowości. Narodziny tożsamości nowoczesnej, transl. M. Gruszczyński. PWN, Warszawa.

Turnbull G. (2003). Observation upon Liberal Education, in All its Branches. T.O. Moore Jr (ed.). Liberty Fund, Indianapolis.

Ward L. (2010). John Locke and Modern Life. Cambridge University Press, Cambridge. Wrońska K. (2012). Pedagogika klasycznego liberalizmu w dwugłosie John Locke i John Stuart Mill. Wydawnictwo Uniwersytetu Jagiellońskiego, Kraków.

Wrońska K. (2015). Uwagi o recepcji twórczości pedagogicznej Johna Locke’a w Polsce z perspektywy pedagogiki filozoficznej, in: S. Sztobryn, K. Kamiński, M. Wasilewski (eds.), Filozofia wychowania w Europie Środkowej w kontekście uwarunkowań historycznych, społecznych, politycznych i filozoficznych. WN TPF „Chowanna”, Łódź, p. 15-35.

Yolton J.W., Yolton J. (2003). Introduction, in: J. Locke, Some Thoughts Concerning Education. Clarendon Press, Oxford. 